ISSN = 1980-993X-doi:10.4136/1980-993X
www.agro.unitau.br/ambi-agua
E-mail: ambi-agua@agro.unitau.br
Tel.: (12) 3625-4116

\title{
Impacts of some divalent cations on periplasmic nitrate reductase and dehydrogenase enzymes of Escherichia, Pseudomonas and Acinetobacter species \\ (doi:10.4136/ambi-agua.48)
}

\author{
${ }^{1}$ Justina C. Orji, ${ }^{2}$ Christian O. Nweke, ${ }^{3}$ Rose N. Nwabueze, Blessing Anyaegbu, \\ Juliet C. Chukwu, Chinyere P. Chukwueke and ${ }^{4}$ Christopher E. Nwanyanwu \\ Department of Microbiology, Federal University of Technology, P.M.B.1526, Owerri, Imo State, Nigéria \\ ${ }^{1}$ chiookolo@yahoo.com; ${ }^{2}$ xrisokey@yahoo.com; ${ }^{3}$ r_n_nwabueze@yahoo.com; \\ ${ }^{4}$ cnwanyanwu2000@yahoo.com
}

\section{ABSTRACT}

The impacts of $\mathrm{Hg}^{2+}, \mathrm{Cd}^{2+}$ and $\mathrm{Zn}^{2+}$ on the activities of periplasmic nitrate reductase (NAP) and dehydrogenase (DHA) enzymes of three organisms isolated from soil and sediment-water interface were analysed in liquid culture studies. NAP and DHA activities were estimated from nitrite and triphenyl formazan produced respectively after $4 \mathrm{~h}$ incubation at $28 \pm 2^{\circ} \mathrm{C}$. $\mathrm{Hg}^{2+}$ completely inhibited NAP activity in Escherichia and Pseudomonas spp. at all the concentrations $(0.2-1 \mathrm{mM})$ while progressive inhibitions of NAP activity were observed in Escherichia and Pseudomonas spp. with increasing concentrations of $\mathrm{Zn}^{2+}$ and $\mathrm{Cd}^{2+}$. Both metals were stimulatory to NAP of Acinetobacter sp. at $0.2-1 \mathrm{mM}$. Apart from stimulation of DHA activity by $\mathrm{Zn}^{2+}(0.2-1 \mathrm{mM})$ in Escherichia sp., $\mathrm{Cd}^{2+}(0.4-1.0 \mathrm{mM})$ in Acinetobacter sp. and (1.0mM) in Pseudomonas sp., all the metals progressively inhibited DHA activities in the three organisms. In Escherichia sp., the activities of the two enzymes were negatively correlated on exposure to $\mathrm{Zn}^{2+}(\mathrm{r}=-0.91)$ and positively correlated $(\mathrm{r}=$ $>0.90$ ) on exposure to $\mathrm{Cd}^{2+}$ and $\mathrm{Hg}^{2+}$. Based on $\mathrm{IC}_{50}$ values of the metals for the DHA and NAP enzymes, the most resistant of the three organisms were Escherichia sp. and Acinetobacter sp. respectively. Quantitatively, NAP with its lower $\mathrm{IC}_{50}$ values than DHA was a more sensitive toxicity measure for $\mathrm{Hg}^{2+}$ in all the organisms. The sensitivity of microbial metabolic enzymes to the toxic effects of metals varies with the type of enzyme, metal and the microorganism involved.

Keywords: Periplasmic nitrate reductase; Dehydrogenase; Escherichia sp.; Pseudomonas sp.; Acinetobacter sp.; $\mathrm{IC}_{50} ; \mathrm{Hg}^{2+} ; \mathrm{Cd}^{2+}$ and $\mathrm{Zn}^{2+}$.

\section{Impactos de alguns cátions divalentes em reductase de nitrato periplásmico e dehydrogenase de enzimas das espécies Escherichia, Pseudomonas e de Acinetobactérias}

\section{RESUMO}

Os impactos do $\mathrm{Hg}^{2+}, \mathrm{Cd}^{2+}$ e $\mathrm{Zn}^{2+}$ nas atividades de reductase do nitrato periplásmico (NAP) e dehidrogenase (DHA) de enzimas em três organismos isolados do solo e da interface sedimento-água foram analisados em estudos de cultura líquida. As atividades de NAP e DHA foram estimadas com o uso de formazan de trifenil formado depois de 4 h de incubação a $28 \pm 2^{\circ} \mathrm{C}$. $\mathrm{O} \mathrm{Hg}^{2+}$ inibiu a atividade da NAP completamente em Escherichia e Pseudomonas 
ORJI, J. C.; NWEKE, C. O.; NWABUEZE, R. N.; ANYAEGBU, B.; CHUKWU, J. C.; CHUKWUEKE, C. P.; NWANYANWU, C. E. Impacts of some divalent cations on periplasmic nitrate reductase and dehydrogenase enzymes of Escherichia, Pseudomonas and Acinetobacter species. Ambi-Agua, Taubaté, v. 3, n. 2, p. 5-18, 2008. (doi:10.4136/ambi-agua.48)

spp em todas as concentrações $(0,2-1 \mathrm{mM})$ enquanto foram observadas inibições progressivas da atividade da NAP em Escherichia e Pseudomonas spp com concentrações crescentes de $\mathrm{Zn}^{2+}$ e $\mathrm{Cd}^{2+}$. Ambos os metais foram estimuladores da NAP em Acinetobactéria sp para $0.2-1 \mathrm{mM}$. Exceto pelo estímulo da atividade DHA pelo $\mathrm{Zn}^{2+}(0.2-1 \mathrm{mM})$ em Escherichia sp, $\mathrm{Cd}^{2+}(0.4-1.0 \mathrm{mM})$ em Acinetobacter sp e (1.0 mM) em Pseudomonas sp, todos os metais progressivamente inibiram atividades de DHA nos três organismos. Em Escherichia sp, as atividades das duas enzimas foram negativamente correlacionadas quando em exposição ao $\mathrm{Zn}^{2+}(\mathrm{r}=-0.91)$ e positivamente correlacionadas $(\mathrm{r}=>0.90)$ quando em exposição ao $\mathrm{Cd}^{2+}$ e $\mathrm{Hg}^{2+}$. Baseado em valores de $\mathrm{IC}_{50}$ dos metais para a DHA e enzimas NAP, os mais resistentes dos três organismos foram a Escherichia sp e Acinetobactéria SP, respectivamente. Quantitativamente, a NAP com seu valor mais baixo de $\mathrm{IC}_{50}$ do que a DHA foi uma medida de toxicidade mais sensível para $\mathrm{Hg}^{2+}$ em todos os organismos. A sensibilidade de enzimas metabólicas microbianas aos efeitos tóxicos de metais varia com o tipo de enzima, metal e com o microorganismo envolvido.

Palavras-chave: Reductase do nitrato periplásmico; dehidrogenase; Escherichia sp; Pseudomonas sp; de Acinetobactéria sp; $\mathrm{IC}_{50} ; \mathrm{Hg}^{2+} ; \mathrm{Cd}^{2}+\mathrm{e} \mathrm{Zn}^{2+}$.

\section{INTRODUCTION}

Denitrification, the conversion of nitrate to its reduced form plays a key role in the nitrogen cycle and has important agricultural, environmental, and public health significance. Nitrate loss from agricultural soil reduces bioavailable nitrogen, hence affects crop yield as well as soil fauna and flora. Denitrification therefore is not a desirable process from an agricultural point of view (Loreau et al., 2001). However in sewage treatment where one of the goals is reduction in nitrate level of wastes before final disposal, denitrification is a desirable process. Various species of Achromobacter, Agrobacterium, Hyphomicrobium, Escherichia, Pseudomonas, Vibrio and others are responsible for denitrification in soil (Otlanabo, 1993). In wastewater treatment plants, a vast array of microbial species which includes Aeromonas, Klebsiella, Enterobacter, Commomonas and Bacillus have been isolated (Lim et al., 2005). Originally thought to be an entirely anaerobic microbial process, denitrification has been found to also occur under aerobic conditions. The enzyme responsible for the aerobic process is a dissimilatory nitrate reductase (NAP) which exists in the periplasm of some Gram-negative bacteria (Ellington et al., 2002; Potter et al., 2001). Isolations from soil and wastewater indicate that aerobic denitrification is widespread in nature. Despite this, the physiological role and the ecological implications of the process are still being elucidated. It was suggested that the roles of the enzyme vary in different organisms and even in the same organism under different metabolic conditions (MorenoVivian et al., 1999). Some of the proposed roles for the process are the disposal of excess reducing equivalents during aerobic growth and nitrate respiration in nitrate-limited environments (Ellington et al., 2002).

Dehydrogenase activity represents the intracellular flux of electrons to oxygen and is due to the activities of several intracellular enzymes catalyzing the transfer of hydrogen and electron from one compound to another (Nannipieri et al., 1990). Its measurement has been used to assess the toxicity of environmental pollutants to microorganisms (Nweke et al., 2006, 2007; Adam and Ducan, 2001). Heavy metal ions such as $\mathrm{Hg}^{2+}, \mathrm{Cd}^{2+}, \mathrm{Zn}^{2+}, \mathrm{Pb}^{2+}$ and other trace metals enter the soil from both natural and anthropogenic sources. These ions have 
ORJI, J. C.; NWEKE, C. O.; NWABUEZE, R. N.; ANYAEGBU, B.; CHUKWU, J. C.; CHUKWUEKE, C. P.; NWANYANWU, C. E. Impacts of some divalent cations on periplasmic nitrate reductase and dehydrogenase enzymes of Escherichia, Pseudomonas and Acinetobacter species. Ambi-Agua, Taubaté, v. 3, n. 2, p. 5-18, 2008. (doi:10.4136/ambi-agua.48)

great ecological significance due to their toxicity and accumulative behavior (Purves, 1985). The interaction between microbes and metals in the environment has been both beneficial and detrimental. Though some have been found essential for many microbial processes, at high concentrations, both essential and non essential metals are known to be toxic to microorganisms (Nies, 1999).

The dehydrogenase enzymes from different microorganisms have been reported to respond differently to environmental stress. Ohnesorge and Wilhem (1991), observed that dehydrogenase activity in Pseudomonas species reduced with increasing concentrations of $\mathrm{Cd}^{2+}$, while in Proteus species, stimulated activity was observed at $\mathrm{Cd}^{2+}$ concentrations of $0.2 \mathrm{mM}$ to $0.4 \mathrm{mM}$ followed by progressive inhibition at concentrations above $0.6 \mathrm{mM}$. Nweke et al. (2006) also observed that $\mathrm{Zn}^{2+}$ at $0.2 \mathrm{mM}$ stimulated dehydrogenase enzyme of Proteus sp PLK2 and Micrococcus sp. PLK4 followed by progressive inhibition thereafter, while in Escherichia sp PLK1 and Pseudomonas sp PLK5 progressive inhibitions were observed at all the concentrations of $\mathrm{Zn}^{2+}$ studied $(0.2-1.2 \mathrm{mM})$. Unlike the dehydrogenase activity, information on the sensitivities of periplasmic nitrate reductase to environmental stress is scarce. However, Bursakov et al., (1997) reported the inhibition of the enzyme in Desulfovibrio desulfuricans ATCC 27774 by divalent cations. In a previous study, Okolo et al. (2007) reported that the periplasmic nitrate reductase of Acinetobacter sp isolated from an agricultural soil was more sensitive to phenolic compounds than the dehydrogenase enzyme of the same organism. For an enzyme such as periplasmic nitrate reductase whose desirability of inhibition or stimulation of activity depends on the specific environment under review, it becomes necessary to investigate the environmental effects of a wide array of stress factors in order to make useful decisions.

In this study, the response to metal exposure of the periplasmic nitrate reductase and dehydrogenase enzymes of organisms isolated from soil and sediment-water interface, which represent two different environments in which nitrate reduction plays different environmental roles is reported.

\section{MATERIALS AND METHODS}

\subsection{Isolation, purification and screening of organisms for nitrate reduction}

Samples were collected randomly from an agricultural farm at a depth of $5 \mathrm{~cm}$ below the soil surface and from the upper $5 \mathrm{~cm}$ of sediment-water interface of Nwaorie River using a sterile metal cylindrical tool. Samples treatment, media and incubation conditions were as previously described (Okolo et al., 2007). Purification and screening for nitrate reduction was done in a defined medium of Celen and Kilic (2004), as modified by Okolo et al. (2007). The modified defined agar medium has the following composition (g/litre): succinic acid, 3.54; $\mathrm{NaOH}, 1.2 ; \mathrm{NH}_{4} \mathrm{Cl}, 0.535 ; \mathrm{Na}_{2} \mathrm{HPO}_{4}, 18 ; \mathrm{KH}_{2} \mathrm{PO}_{4}, 1.0 ; \mathrm{NaCl}, 2.5 ; \mathrm{MgSO}_{4}, 0.1 ; \mathrm{FeSO}_{4}, 1.11 ;$ fungicide (Ketoconazole), 0.05; agar 17; pH 7.2.

The selected organisms were stored on slants of the defined medium prior to characterisation up to the generic level following the schemes of Holt et al. (1994).

\subsection{Preparation of inoculum}

The organisms were plated on the modified defined medium (Okolo et al., 2007) containing $10 \mathrm{mM} \mathrm{KNO}_{3}$ instead of the $10 \mathrm{mM} \mathrm{NH}_{4} \mathrm{Cl}$ and incubated at room temperature (28 $\pm 2{ }^{\circ} \mathrm{C}$ ) for two days. The cultures were washed, harvested and standardized by resuspending in phosphate buffered saline and adjusting the turbidity to give an optical density of 0.4 at 600 
ORJI, J. C.; NWEKE, C. O.; NWABUEZE, R. N.; ANYAEGBU, B.; CHUKWU, J. C.; CHUKWUEKE, C. P.; NWANYANWU, C. E. Impacts of some divalent cations on periplasmic nitrate reductase and dehydrogenase enzymes of Escherichia, Pseudomonas and Acinetobacter species. Ambi-Agua, Taubaté, v. 3, n. 2, p. 5-18, 2008. (doi:10.4136/ambi-agua.48)

$\mathrm{nm}$ as previously described (Okolo et al., 2007). The cell suspensions served as the standardized inocula for the studies. The dry weights of the cells were estimated by drying a 2 $\mathrm{ml}$ aliquot of the standardized cell suspensions to constant weight in a pre-weighed crucible in an oven at $105^{\circ} \mathrm{C}$.

\subsection{Assay for toxicity of metals to enzyme activities}

Portions $(0.2 \mathrm{ml})$ of the standardized cell suspensions were inoculated into sterile triplicate $20 \mathrm{ml}$ screw-capped glass tubes containing $4.8 \mathrm{ml}$ of the modified defined medium supplemented with a particular concentration $(0.2-1.0 \mathrm{mM})$ of the various metals $\left(\mathrm{Zn}^{2+}\right.$, $\mathrm{Cd}^{2+}$ and $\mathrm{Hg}^{2+}$ ) prepared in the modified defined medium (Okolo et al., 2007) devoid of nitrate $\left(\mathrm{KNO}_{3}\right)$ and agar. The control consisted of the inoculated medium without the metals.

Incubation conditions and assays for the periplasmic nitrate reductase and dehydrogenase activities were as described earlier (Okolo et al., 2007). Nitrite concentrations and the amount of formazan produced in the samples were estimated by reference to standard dose-response curves. Periplasmic nitrate reductase (NAP) activity was expressed relative to the amount of nitrite formed while dehydrogenase (DHA) activity was expressed as milligrams of triphenyl formazan (TPF) formed per mg dry weight of cell biomass per hour.

\subsection{Calculation of inhibition or stimulation of enzyme activity}

Inhibitions or stimulations of the enzyme activities were calculated relative to the controls. Where applicable, the $\mathrm{IC}_{50}$ and $\mathrm{IC}_{20}$ of the metals were determined by fitting the percentage inhibition values to simple equations using Table 2D Curve (Systat Inc., USA) and calculating the concentrations of the metals at $50 \%$ inhibition of enzyme activity.

\subsection{Statistical analysis}

Data generated were subjected to multiple factor analyses of variance (ANOVA). Relationships between the effects of divalent cations on enzyme activities were analyzed using regression analyses and the Pearson's product-moment correlation coefficient.

\section{RESULTS AND DISCUSSION}

The isolate from the sediment-water interface was identified as Escherichia sp while those from soil were identified as Pseudomonas and Acinetobacter spp. The three organisms are Gram negative non-spore-forming rods and members of these genera are often ubiquitous and exhibit a great deal of metabolic versatility. Members of the genus Pseudomonas demonstrate a great deal of metabolic diversity, and consequently are able to colonise a wide range of niches (Madigan and Martinko, 2005). The Acinetobacter have been attracting growing interest in both environmental and biotechnological applications because they possess characteristics which are being exploited in various biotechnological applications including bioremediation of heavy metal contaminated waters (Boswell et al., 1999). According to Otlanabo (1993), various species of Escherichia and Pseudomonas among others are responsible for denitrification occurring in incredible diverse microbial consortia as that in wastewater.

The demonstration of a periplasmic nitrate reductase (NAP) activity by these organisms is proved by the experimental protocols used in the study. Nitrate reduction in bacteria is brought about by the activities of three nitrate reductases which are active under different physiological conditions. These are the cytoplasmic nitrate reductase (NAS), membrane- 
bound nitrate reductase (NAR) and the periplasmic nitrate reductase (NAP). The activity of NAS is repressed by ammonium in the isolation medium while that of NAR is repressed under the aerobic conditions used in the study. NAP is not affected by ammonium or oxygen (Celen and Kilic, 2004; Simon et al., 2003).

The results of the effects of different concentrations of $\mathrm{Zn}^{2+}, \mathrm{Cd}^{2+}$ and $\mathrm{Hg}^{2+}$ on the NAP and dehydrogenase (DHA) activities of Escherichia, Acinetobacter and Pseudomonas species are shown in Figures 1 and 2. NAP activity was most prolific in Acinetobacter sp., yielding $2.19 \mu \mathrm{\mu NO}_{2}-\mathrm{N} / \mathrm{ml}$ in the control treatment (Figure 1) while DHA activities were comparable in all the organisms. In all the organisms, differences in the responsiveness of NAP and DHA to increasing concentrations of the three metals were significant $(\mathrm{P}<0.5)$. Except $\mathrm{Hg}^{2+}$ which completely inhibited NAP activities in Escherichia and Pseudomonas spp at all the concentrations, responses of the enzymes to the metals were dose-dependent. Increasing concentrations of $\mathrm{Zn}^{2+}$ and $\mathrm{Cd}^{2+}$ resulted to progressive reductions in nitrite production in Escherichia and Pseudomonas spp. (Figure 1). In Acinetobacter sp., sharp increases in NAP activities were observed on exposure to $\mathrm{Zn}^{2+}$ and $\mathrm{Cd}^{2+}$ at $0.2 \mathrm{mM}$, thereafter, progressive reduction in activities followed (Figure 1). High toxicity of $\mathrm{Hg}^{2+}$ reported in various microbes has been attributed to its very high affinity to thiol groups (Nies, 1999). This has tremendous relevance in this study because the molecular structures of NAP show that cysteine provides a thiol ligand to the molybdenum cofactor at the active sites of the enzyme (Jepson et al., 2004). In a similar study, Bursakov et al. (1997) reported the inhibition of NAP activities in Desulfovibrio desulfuricans ATCC 27774 by divalent cations. The increase in NAP activity of Acinetobacter sp at $\mathrm{Cd}^{2+}(0.2-1.0 \mathrm{mM})$ indicates that $\mathrm{Cd}^{2+}$ at the stated concentrations might be a cofactor for the enzyme in the organism. Apart from stimulation of DHA by $\mathrm{Zn}^{2+}(0.2-1 \mathrm{mM})$ in Escherichia sp, by $\mathrm{Cd}^{2+}(0.4-1.0 \mathrm{mM})$ in Acinetobacter sp., and by $\mathrm{Cd}^{2+}(1.0 \mathrm{mM})$ in Pseudomonas sp, all the metals inhibited DHA activities at various degrees in the three organisms (Figure 2). Nweke et al. (2006) reported that $\mathrm{Zn}^{2+}$ at $0.2 \mathrm{mM}$ stimulated DHA of Proteus sp PLK2 and Micrococcus sp. PLK4 isolated from a river water sample and thereafter progressive inhibition followed at higher concentrations. In the same study, however, Nweke et al. (2006) noted progressive inhibition of DHA activities in Escherichia sp PLK1 and Pseudomonas sp PLK5 at all the concentrations of $\mathrm{Zn}^{2+}$ studied (0.2-1.2mM). These differences in the responsiveness of DHA enzymes from different organisms exposed to $\mathrm{Zn}^{2+}$ could be attributed to variations in cell wall components of microorganisms and might also be related to genetic factors of metal resistance among the organisms. Although $\mathrm{Zn}^{2+}$ is an essential trace element that plays vital role in cell growth, differentiation and development, (Ohnesorge and Wilhelm, 1991), it is known to be a potent inhibitor of the respiratory electron transport system (Beard et al., 1995). 
ORJI, J. C.; NWEKE, C. O.; NWABUEZE, R. N.; ANYAEGBU, B.; CHUKWU, J. C.; CHUKWUEKE, C. P.; NWANYANWU, C. E. Impacts of some divalent cations on periplasmic nitrate reductase and dehydrogenase enzymes of Escherichia, Pseudomonas and Acinetobacter species. Ambi-Agua, Taubaté, v. 3, n. 2, p. 5-18, 2008. (doi:10.4136/ambi-agua.48)

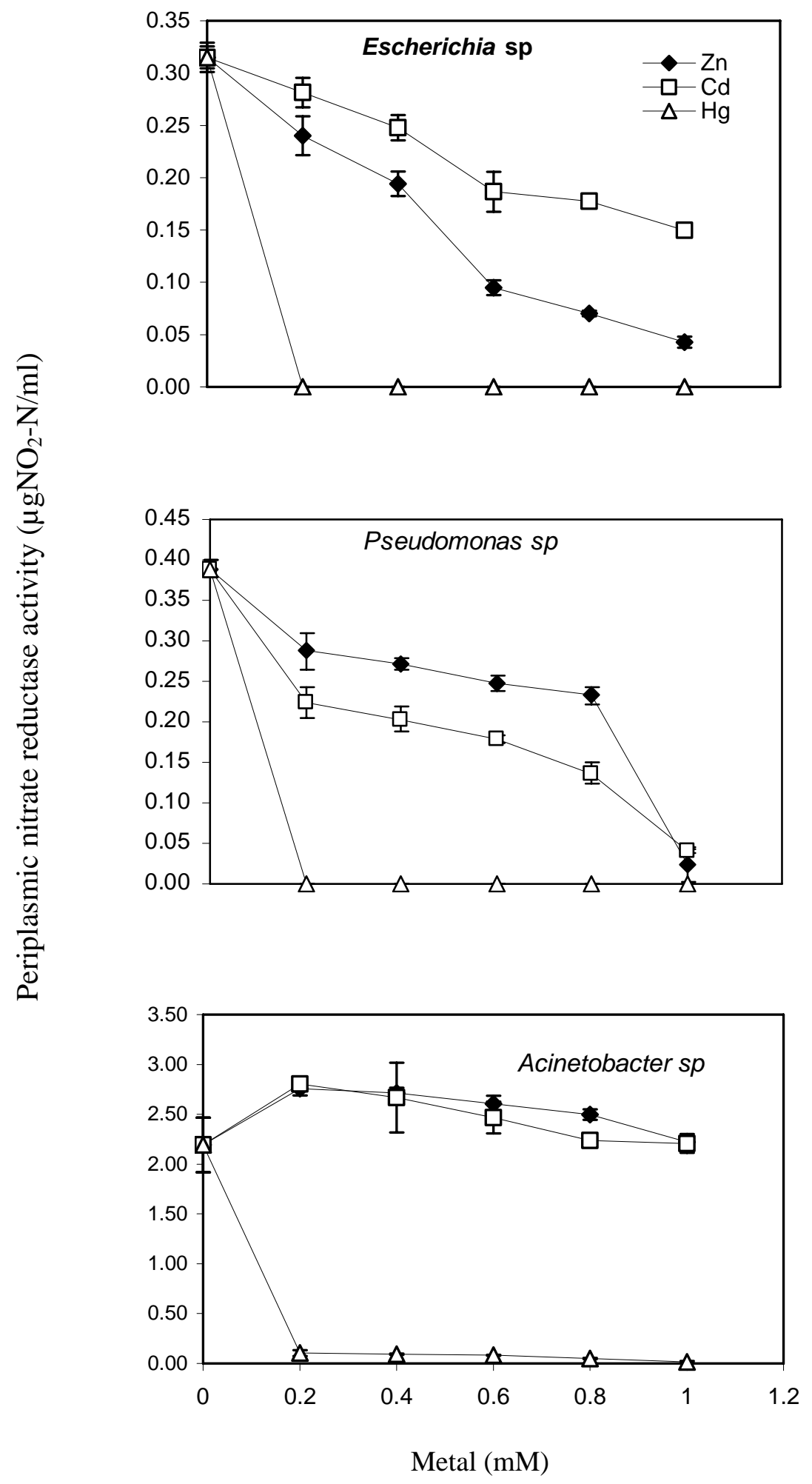

Figure 1. Effects of metals on periplasmic nitrate reductase activities of the bacterial strains. 
ORJI, J. C.; NWEKE, C. O.; NWABUEZE, R. N.; ANYAEGBU, B.; CHUKWU, J. C.; CHUKWUEKE, C. P.; NWANYANWU, C. E. Impacts of some divalent cations on periplasmic nitrate reductase and dehydrogenase enzymes of Escherichia, Pseudomonas and Acinetobacter species. Ambi-Agua, Taubaté, v. 3, n. 2, p. 5-18, 2008. (doi:10.4136/ambi-agua.48)

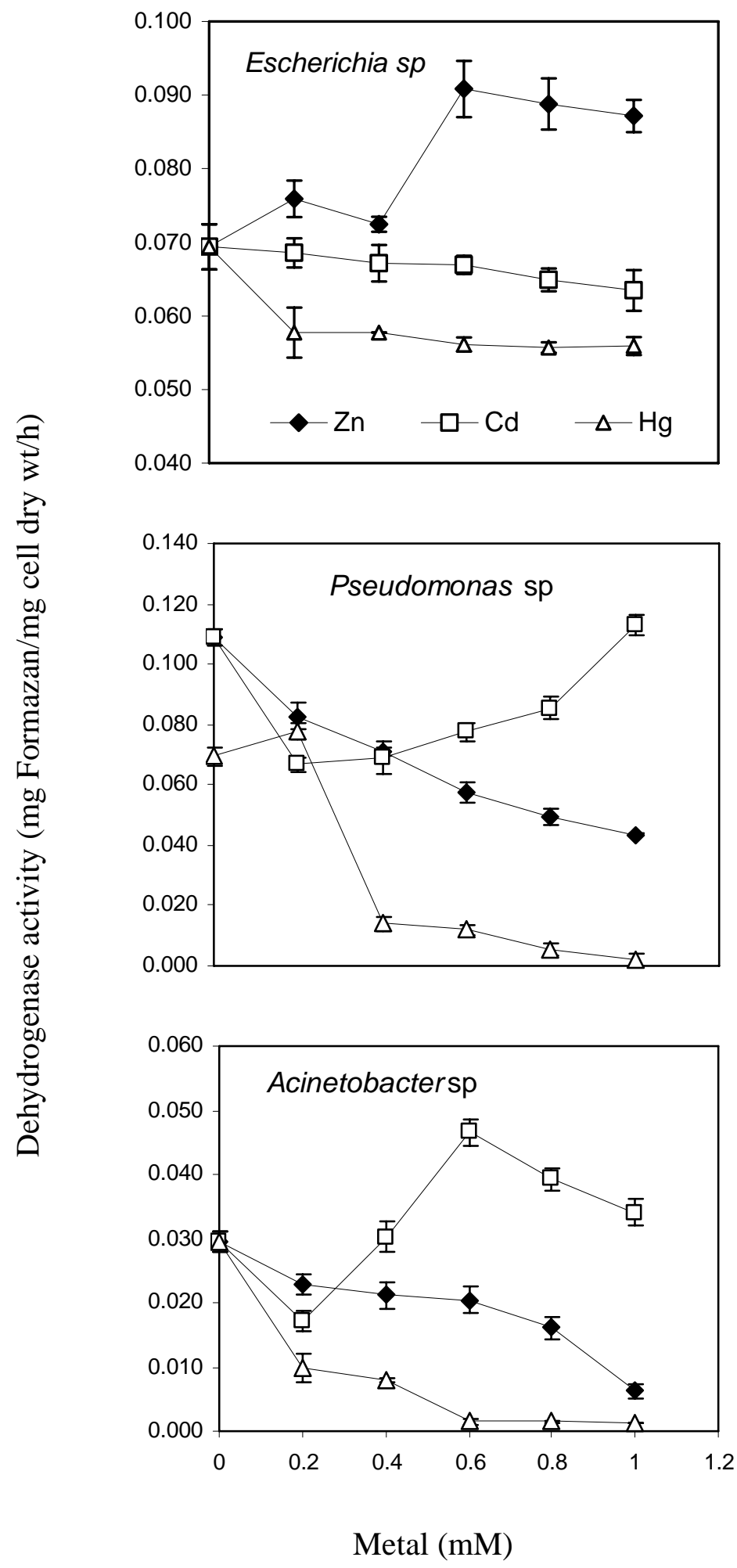

Figure 2. Effects of metals on dehydrogenase activities of the bacterial strains. 
ORJI, J. C.; NWEKE, C. O.; NWABUEZE, R. N.; ANYAEGBU, B.; CHUKWU, J. C.; CHUKWUEKE, C. P.; NWANYANWU, C. E. Impacts of some divalent cations on periplasmic nitrate reductase and dehydrogenase enzymes of Escherichia, Pseudomonas and Acinetobacter species. Ambi-Agua, Taubaté, v. 3, n. 2, p. 5-18, 2008. (doi:10.4136/ambi-agua.48)

With respect to increasing concentrations of $\mathrm{Cd}^{2+}$, the response of the DHA enzymes of the organisms varied markedly. In Escherichia sp., slight reductions in formazan production were observed as $\mathrm{Cd}^{2+}$ concentrations increased (Figure 2). On the contrary, in Pseudomonas sp., lower concentrations of $\mathrm{Cd}^{2+}$ inhibited formazan production while increased production was observed at $1.0 \mathrm{mM} \mathrm{Cd}^{2+}$ (Figure 2). In Acinetobacter sp., an initial decrease in formazan production was observed at a $\mathrm{Cd}^{2+}$ concentration of $0.2 \mathrm{mM}$, thereafter, formazan production increased with increasing concentrations of $\mathrm{Cd}^{2+}$ up to $0.6 \mathrm{mM}$. Above $0.6 \mathrm{mM}$, a further increase in $\mathrm{Cd}^{2+}$ concentrations led to a decrease in formazan production (Figure 2). The stimulatory effects of $\mathrm{Cd}^{2+}$ indicate that it could be a necessary cofactor for the DHA of the Pseudomonas sp at $1.0 \mathrm{mM}$ and for the Acinetobacter sp. at $0.6 \mathrm{mM}$. This report is however contrary to the observations of Liao et al. (2005), in which dehydrogenase activity decreased with increasing $\mathrm{Cd}^{2+}$ concentrations. These variations in responses of the DHA enzymes from different microorganisms exposed to metal ions could be accounted for by the fact that dehydrogenase systems differ in organisms (Praveen-Kumar, 2003).

The associations between the activities of NAP and DHA enzymes of the three organisms were estimated using the Pearson's product moment correlation coefficient. Results indicated that negative correlations existed between the two enzymes on exposure of Escherichia sp. to $\mathrm{Zn}^{2+}(\mathrm{r}=-0.91)$ and of Pseudomonas and Acinetobacter spp. to $\mathrm{Cd}^{2+}(\mathrm{r}=-$ 0.01 and -0.49 respectively). Apart from these, associations between the two enzymes in the three organisms in response to increasing concentrations of the metals were positively correlated. This positive correlation was strong $(>0.9)$ in Escherichia sp in response to $\mathrm{Cd}^{2+}$ and $\mathrm{Hg}^{2+}$, and in Acinetobacter sp. in response to $\mathrm{Hg}^{2+}$. In a similar study, Okolo et al. (2007), reported a positive correlation between NAP and DHA enzymes of Acinetobacter sp. exposed to various doses of phenolic compounds and attributed it to the fact that both enzymes are membrane associated. Metals are also known to have effects which directly or indirectly disrupt microbial membranes. It has been suggested that $\mathrm{Zn}^{2+}$ binds to the membranes of microorganisms, and both organic and inorganic mercurials interfere with membrane permeability and enzyme reactions through binding to sulfhydryl groups (Eisler, 2006) and forming nonspecific intracellular complexes with thiol groups (Nies, 1999). Since the microbial process being investigated is aerobic nitrate reduction, interactions of these nonspecific complexes with molecular oxygen could lead to the formation of reactive oxygen species resulting in oxidative stress within the organisms (Kachur et al., 1998). Furthermore, the three organisms under study are Gram-negative organisms and it has been reported that in Gram-negative bacteria, heavy metal cations can bind to glutathione, a notable antioxidant, resulting in considerable oxidative stress (Kachur et al., 1998; Nies, 1999). The strong negative correlation of both enzymes in Escherichia sp. exposed to $\mathrm{Zn}^{2+}$ meant that though the enzymes were membrane-associated, the toxic effect of the metal on one of the enzymes might not be membrane related. Since NAP is active in the periplasmic membrane while DHA enzyme is active intracellularly, it appears that for Escherichia sp., $\mathrm{Zn}^{2+}$ is toxic only in the periplasmic membrane.

The relative inhibitory/stimulatory effects of the different concentrations of the metals on NAP and DHA activities of Escherichia, Pseudomonas and Acinetobacter spp. are shown in Figures 3 and 4 respectively. $\mathrm{Hg}^{2+}$ at all the concentrations studied, gave $100 \%$ inhibition of NAP activities in Escherichia and Pseudomonas spp. and $>90 \%$ inhibition in Acinetobacter sp. (Figure 3). The inhibition ranges of NAP in response to increasing concentrations of $\mathrm{Zn}^{2+}$ were 22.38 - 83.81\% for Escherichia sp.; 24.81 - 91.47 \% for Pseudomonas sp.; and for the Acinetobacter sp., $\mathrm{Zn}^{2+}$ was stimulatory. For the DHA enzyme, $\mathrm{Zn}^{2+}$ was stimulatory to 
Escherichia sp. at all the concentrations while $\mathrm{Cd}^{2+}$ was also stimulatory to Acinetobacter sp. above $0.2 \mathrm{mM}$ (Figure 4). The inhibitory threshold concentrations (Table 1) of the metals for the NAP and DHA enzymes were calculated from the percentage inhibition values versus toxicant concentration plots (not shown) by fitting data into simple equations. Readings are taken from regression curves with high coefficients of determination $\left(0.9 \leq R^{2} \leq 1.0\right)$. The inhibitory threshold concentrations for the DHA enzyme which is a measure of the general microbial activity shows that Escherichia sp., being stimulated by $\mathrm{Zn}^{2+}$ and having an $\mathrm{IC}_{50}$ of $>1$ for $\mathrm{Hg}^{2+}$ is the most resistant of the three organisms to the effects of these metals. Greater resistance of Escherichia sp might not be unrelated to the fact that the organism was isolated from the sediment-water interface of a river where hospitals, schools and industries discharge their effluents. Such effluents might contain a variety of heavy metals to which the species might have adapted. Nweke et al. (2006), reported an $\mathrm{IC}_{50}$ of $0.301 \mathrm{mM}$ for $\mathrm{Zn}^{2+}$ for the DHA of Escherichia sp. PLK1 while Pérez-Garcia et al. (1993) reported an $\mathrm{IC}_{50}$ of $0.999 \mathrm{mM}$ for $\mathrm{Zn}^{2+}$ for the DHA of Pseudomonas fluorescens. Apart from the sources of organisms, these variabilities in inhibitory threshold concentrations might not be unrelated to experimental protocols like media composition and $\mathrm{pH}$ which affect solution-phase metal concentrations (Nies, 1999) which were analysed in the studies cited.

With respect to NAP activity, Acinetobacter sp. is the most resistant, being stimulated by both $\mathrm{Zn}^{2+}$ and $\mathrm{Cd}^{2+}$, and showing some degree of tolerance to some concentrations of $\mathrm{Hg}^{2+}$. Quantitatively, NAP with its lower $\mathrm{IC}_{50}$ values $(<0.2 \mathrm{mM})$ was a more sensitive toxicity measure than DHA activity for $\mathrm{Hg}^{2+}$ in all the organisms, while DHA with lower $\mathrm{IC}_{50}$ values was a more sensitive toxicity measure than NAP for $\mathrm{Zn}^{2+}$ and $\mathrm{Cd}^{2+}$ in Pseudomonas sp. Results in other organisms are varied. In Pseudomonas sp., $\mathrm{Hg}^{2+}$ is a more sensitive metal toxicity measure of NAP activity than DHA. The implication of this therefore is that the sensitivity of microbial metabolic enzymes to the toxic effects of metals varies with the type of enzyme, metal and the microorganism involved. 
ORJI, J. C.; NWEKE, C. O.; NWABUEZE, R. N.; ANYAEGBU, B.; CHUKWU, J. C.; CHUKWUEKE, C. P.; NWANYANWU, C. E. Impacts of some divalent cations on periplasmic nitrate reductase and dehydrogenase enzymes of Escherichia, Pseudomonas and Acinetobacter species. Ambi-Agua, Taubaté, v. 3, n. 2, p. 5-18, 2008. (doi:10.4136/ambi-agua.48)

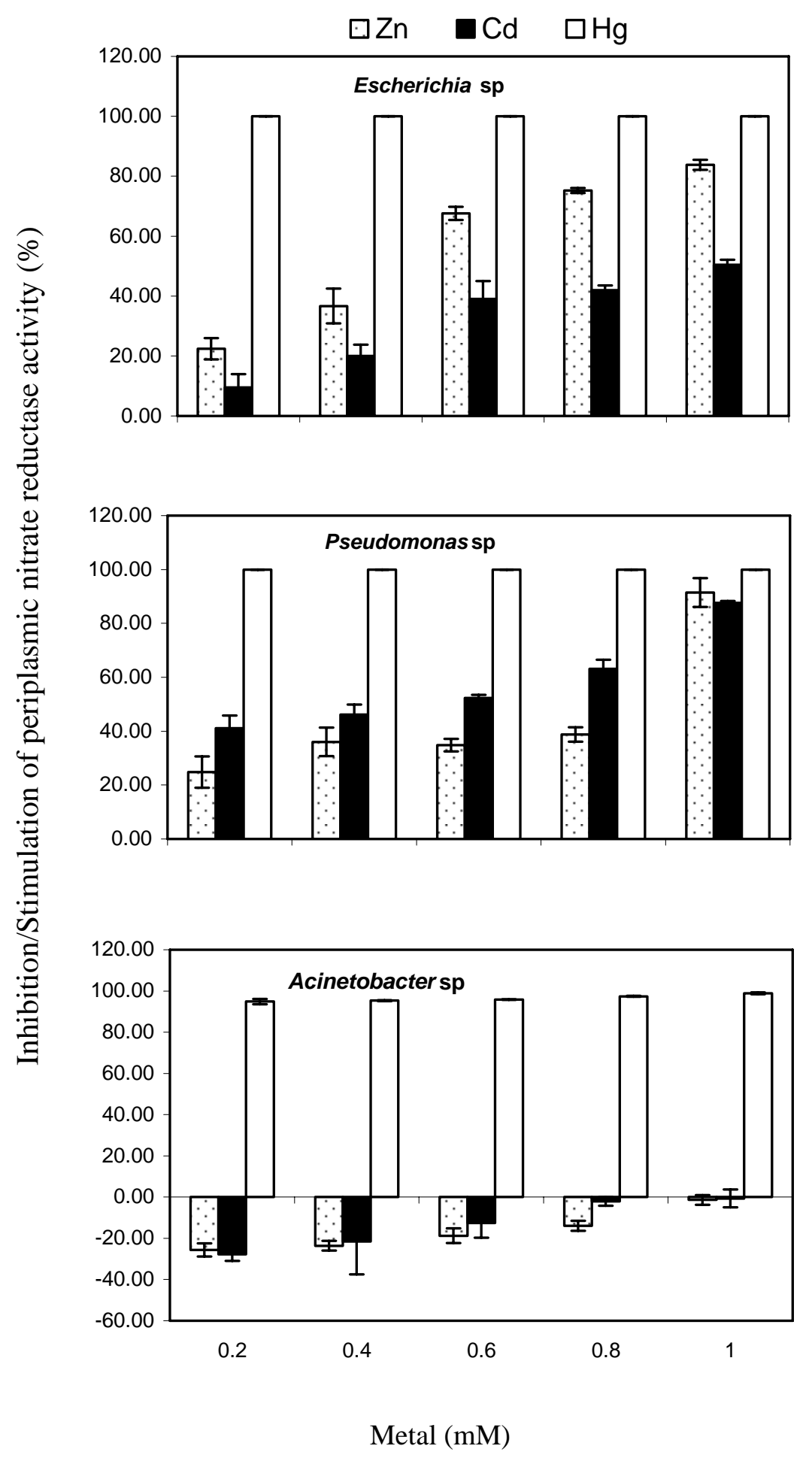

Figure 3. Relative effects of metals on periplasmic nitrate reductase activities of the bacterial strains. $(>0 \%=$ Inhibition; $<$ $0 \%=$ Stimulation $)$. 
ORJI, J. C.; NWEKE, C. O.; NWABUEZE, R. N.; ANYAEGBU, B.; CHUKWU, J. C.; CHUKWUEKE, C. P.; NWANYANWU, C. E. Impacts of some divalent cations on periplasmic nitrate reductase and dehydrogenase enzymes of Escherichia, Pseudomonas and Acinetobacter species. Ambi-Agua, Taubaté, v. 3, n. 2, p. 5-18, 2008. (doi:10.4136/ambi-agua.48)
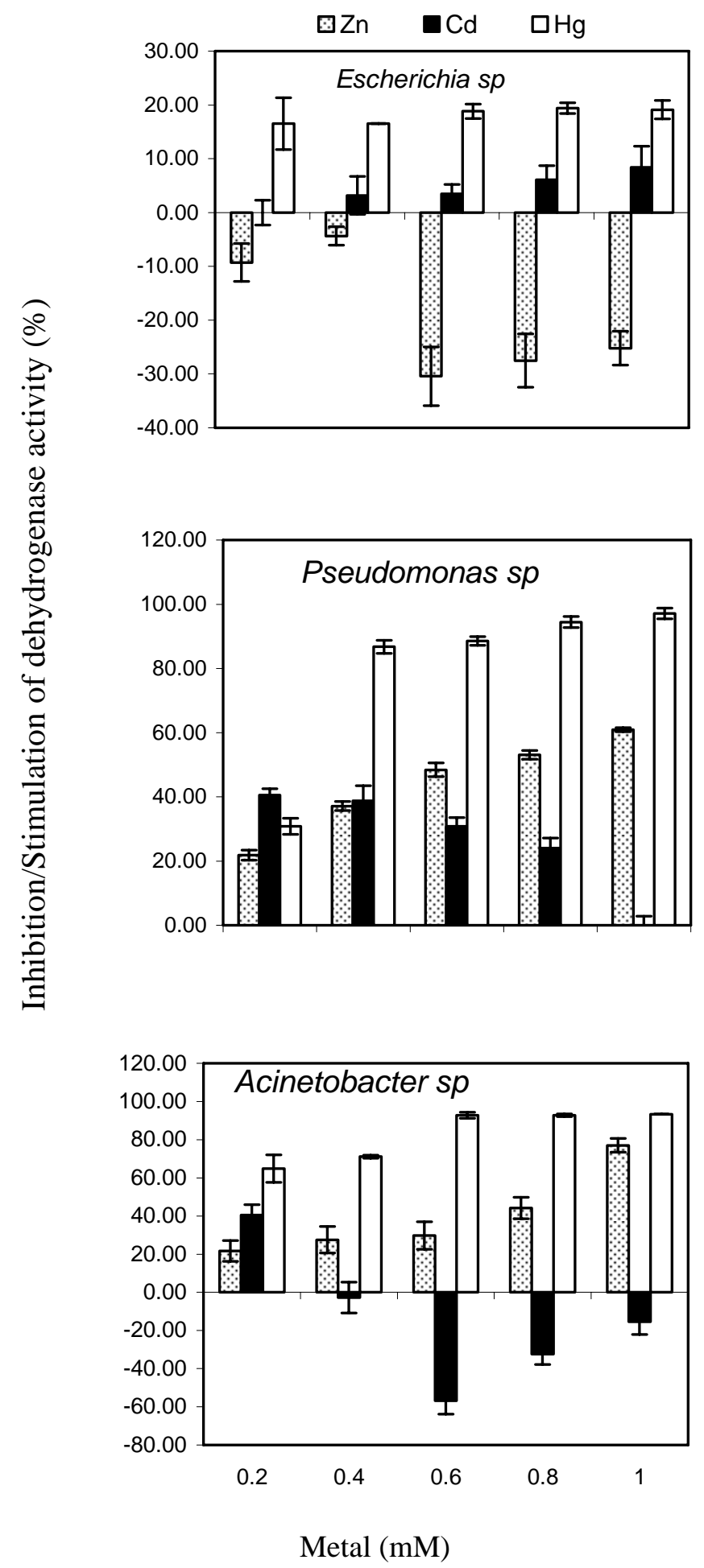

Figure 4. Relative effects of metals on dehydrogenase activities of the bacterial strains. $(>0 \%=$ Inhibition; $<$ $0 \%=$ Stimulation).

Table 1. Threshold inhibitory concentrations of heavy metals against bacterial strains. 
ORJI, J. C.; NWEKE, C. O.; NWABUEZE, R. N.; ANYAEGBU, B.; CHUKWU, J. C.; CHUKWUEKE, C. P.; NWANYANWU, C. E. Impacts of some divalent cations on periplasmic nitrate reductase and dehydrogenase enzymes of Escherichia, Pseudomonas and Acinetobacter species. Ambi-Agua, Taubaté, v. 3, n. 2, p. 5-18, 2008. (doi:10.4136/ambi-agua.48)

\begin{tabular}{|c|c|c|c|c|c|c|c|}
\hline \multirow{3}{*}{ Bacteria } & \multirow{3}{*}{ Metal } & \multicolumn{6}{|c|}{ Inhibition threshold concentrations (mM) } \\
\hline & & \multicolumn{3}{|c|}{ Dehydrogenase activity } & \multicolumn{3}{|c|}{ Periplasmic nitrate reductase } \\
\hline & & Model & $\mathrm{IC}_{50}$ & $\mathrm{R}$ & Model & $\mathrm{IC}_{50}$ & $\mathrm{R}$ \\
\hline \multirow{3}{*}{$\begin{array}{l}\text { Pseudomonas } \\
\text { sp. }\end{array}$} & Zinc & $\mathrm{LDRM}^{\mathrm{a}}$ & 0.697 & 1.0 & Poly2 $^{\mathrm{a}}$ & 0.775 & 0.91 \\
\hline & Cadmium & Poly 3 & $<0.2$ & 0.99 & Poly2 $2^{\mathrm{b}}$ & 0.71 & 0.98 \\
\hline & Mercury & LDRM & 0.283 & 1.0 & LDRM & $<0.2$ & 1.0 \\
\hline \multirow{3}{*}{$\begin{array}{l}\text { Acinetobacte } \\
r \text { sp. }\end{array}$} & Zinc & LDRM & 0.85 & 1.0 & Stimulatory & - & - \\
\hline & Cadmium & Stimulatory & - & - & Stimulatory & - & - \\
\hline & Mercury & LDRM & 0.175 & 0.97 & LDRM & $\begin{array}{l}0.0016 \\
5\end{array}$ & 1.0 \\
\hline \multirow{2}{*}{$\begin{array}{l}\text { Escherichia } \\
\text { sp. }\end{array}$} & Zinc & Stimulatory & - & - & LDRM & 0.443 & 0.98 \\
\hline & $\begin{array}{l}\text { Cadmium } \\
\text { Mercury }\end{array}$ & $\begin{array}{l}\text { LDRM } \\
\text { LDRM }\end{array}$ & $\begin{array}{l}>1.0 \\
>1.0\end{array}$ & $\begin{array}{l}0.96 \\
0.99\end{array}$ & $\begin{array}{l}\text { LDRM } \\
\text { LDRM }\end{array}$ & $\begin{array}{l}0.961 \\
<0.2\end{array}$ & $\begin{array}{l}0.98 \\
1.0\end{array}$ \\
\hline
\end{tabular}

${ }^{\mathrm{a}}$ Logistic Dose Response Model, $\mathrm{y}=\mathrm{a} / 1+(\mathrm{x} / \mathrm{b})^{\mathrm{c}}$

Polynomial 3: $\mathrm{Y}=-133.79 \mathrm{x} 3+158.91 \mathrm{x} 2-77.545 \mathrm{x}+49.174$

Polynomial $2^{\mathrm{a}}: \mathrm{Y}=173.99 \mathrm{X}^{2}-134.43 \mathrm{X}+49.74$

Polynomial $2^{\mathrm{b}}: \mathrm{Y}=103.69 \mathrm{X}^{2}-56.68 \mathrm{X}+38.06$

$\mathrm{Y}=$ Inhibition (\%); $\mathrm{X}=$ Metal concentration (mM); a, b and c are model parameters

\section{CONCLUSIONS}

Findings from this study further lends credence to the earlier observations of Okolo et al., (2007) that toxic effects of chemicals on specific oxidative microbial metabolism such as aerobic denitrification are better studied using the specific enzyme involved. Furthermore, the different sensitivities of NAP and DHA enzymes from different organisms to environmental stress are indications that generalizations on the impacts of stress factors on microbial metabolic enzymes need to be made with caution.

\section{REFERENCES}

ADAM, G.; DUCAN, H. Development of a sensitive and rapid method for the measurement of total microbial activity using fluorescein diacetate (FDA) in a range of soils. Soil Biology \& Biochemistry, v. 33, p. 943-951, 2001.

BEARD, S. J.; HUGHES, M. N.; POOLE, R. K. Inhibition of the cytochrome bd-terminated NADH oxidase system in Escherichia coli K-12 by divalent metal cations. FEMS Microbiology Letters, v. 131, p. 205-210, 1995.

BOSWELL, C. D.; DICK, R. E.; MACASKIE, L. E. The effect of heavy metals and other environmental conditions on the anaerobic phosphate metabolism of Acinetobacter johnsonii. Microbiology, v. 145, p. 1711-1720, 1999.

BURSAKOV, S. A.; CARNEIRO, C.; ALMENDRA, M. J.; DUARTE, R. O.; CALDEIRA, J.; MOURA, I. et al. Enzymatic Properties and Effect of Ionic Strength on Periplasmic Nitrate Reductase (NAP) from Desulfovibrio desulfuricans ATCC 27774. Biochem. Biophys. Res. Commun., v. 239, p. 816-822. 1997.

CELEN, E.; KILIC, M. Isolation and characterization of aerobic denitrifiers from agricultural Soil. Turkish Journal of Biology, v. 28, p. 9 - 14. 2004. 
EISLER, R. Mercury Hazards to Living Organisms. London: CRC Press, 2006. 42p.

ELLINGTON, M. J. K.; BHAKOO, K. K.; SAWERS, G.; RICHARDSON, D. J.; FERGUSON, S. J. Hierarchy of Carbon source selection in Paracoccus pantotrophus: strict correlation between reduction state of the Carbon substrate and aerobic expression of the nap operon. Journal of Bacteriology, v. 184, p. 4767-4774, 2002.

HOLT, J. G.; KRIEG, N. R.; SNEATH, P. H. A.; STALEY, J. T.; WILLIAMS, S. T. Bergey's Manual of Determinative Bacteriology. 9. ed. Baltimore: The William and Wilkins Co., 1994. 492-530p

JEPSON, B. J.; ANDERSON, L. J.; RUBIO, L. M.; TAYLOR, C. J.; BUTLER, C. S.; FLORES, E. et al. Tuning a nitrate reductase for function: the first spectropotentiometric characterization of a bacterial assimilatory nitrate reductase reveals novel redox properties. The Journal of Biological Chemistry, v. 279, p. 32212-32218, 2004.

KACHUR, A. V.; KOCH, C. J.; BIAGLOW, J. E. Mechanism of copper catalyzed oxidation of glutathione. Free Radic. Res., v. 28, p 259-269, 1998.

LIAO, M.; LUO, Y.; ZHAO, X.; HUANG, C. Toxicity of cadmium to soil microbial biomass and its activity: effect of incubation time on cadmium ecological dose in a paddy soil. $\mathbf{J}$ Zhejiang Univ Sci. v. 6, p. 324-330, 2005.

LIM, Y; LEE, S.; KIM, S.; YONG, H.; YEON, S.; PARK, Y. et al. Diversity of denitrifying dacteria isolated from daejeon sewage treatment plant. The Journal of Microbiology, v. 43, p. 383-3901, 2005.

LOREAU, M.; NAEEM, S.; INCHAUSTI, P.; BENGTSSON, J.; GRIME, J. P.; HECTOR, A. Biodiversity and ecosystem functioning: current knowledge and future challenges. Science, v. 294, p. 804-808, 2001.

MADIGAN, M.; MARTINKO, J. (Eds.) Brock Biology of Microorganisms. 11. ed. New Jersey: Prentice Hall, 2005.

MORENO-VIVIAN, C.; CABELLO, P.; MARTINEZ-LUQUE, M.; BLASCO, R.; CASTILLO, F. Prokaryotic nitrate reduction: molecular properties and functional distinction among bacterial nitrate reductases. Journal of Bacteriology, v. 181, p. 6573-6584, 1999.

NANNIPIERI, P.; GREGO, S.; CECCANTI, B. Ecological significance of biological activity. In: BOLLAG, J. M.; STOTZKY, G. (Eds.). Soil Biochemistry. New York: Dekker, 1990. Vol. 6. p. 293-355.

NIES, D. H. Microbial heavy-metal resistance. Appl. Microbiol. Biotechnol., v. 51, p. 730750, 1999.

NWEKE, C. O.; OKOLO, J. C.; NWANYANWU, C. E.; ALISI, C. S. Response of planktonic bacteria of New Calabar River to zinc stress. African Journal of Biotechnology, v. 5, p. 653-658, 2006. 
NWEKE, C. O.; ALISI, C. S.; OKOLO, J. C.; NWANYANWU, C. E. Toxicity of zinc to Heterotrophic Bacteria from a tropical river sediment. Applied Ecology and Environmental Research, v. 5, p. 123-132, 2007.

OHNESORGE, F. K.; WILHELM, M. Metals and their compounds in the environment. In: MARIAM, E. (Ed.). Weinheim: Wiley-VHC, 1991.

OKOLO, J. C.; NWEKE, C. O.; NWABUEZE, R. N.; DIKE, C. U.; NWANYANWU, C. E.

Toxicity of phenolic compounds to oxidoreductases of Acinetobacter species isolated from a tropical soil. Scientific Research and Essay, v. 2, p. 244-250, 2007.

OTLANABO, N. L. Denitrification of ground water for potable purposes. WRC Report, v. 403, n. 1, 1993.

PÉREZ-GARCIA, A.; CODINA, J. C.; CAZORLA, F. M.; DE VICENTE, A. Rapid respirometric toxicity test: sensitivity to metals. Bulletin of Environmental Contamination and Toxicology, v. 50, p. 703-708, 1993.

POTTER, L.; ANGOVE, H.; RICHARDSON, D. J.; COLE, J. A. Nitrate reduction in the periplasm of Gram-negative bacteria. Adv. Microb. Physiol., v. 45, p. 51-112, 2001.

PRAVEEN-KUMAR, J. C. T. 2,3,5-Triphenyl chloride (TTC) as electron acceptor of culturable soil bacteria, fungi and actinomycetes. Biology and Fertility of Soils, v. 38, p. 186-189, 2003.

PURVES, D. Trace-elements contamination of the environment. Armsterdam: Elsevier, 1985.

SIMON, J.; SÄNGER, M.; SCHUSTER, S. C.; GROSS, R. Electron transport to periplasmic nitrate reductase (NapA) of Wolinella succinogenes is independent of a NapC protein. Mole. Microbiol., v. 49, p. 69-79, 2003. 